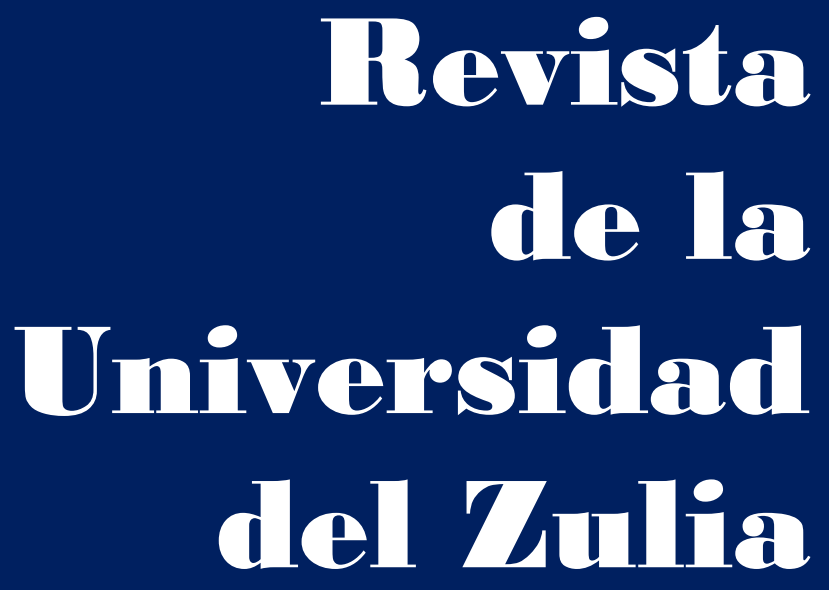

Fundada en 1947

por el Dr. Jesús Enrique Lossada

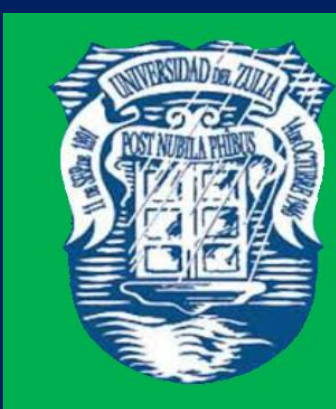

Ciencias del

Agred

Ingemieria

y Teenología
Añต 12 No 32

Enero - Abril 2021

Tercera Época

Maracailbo-Venezuela 


\title{
The organization technology of Ukrainian logistic operators' work on an e-commerce basis
}

\author{
Hanna O. Prymachenko* \\ Anton O. Kovalov** \\ Hanna I. Shelekhan*** \\ Julia V. Shuldiner**** \\ Yelyzaveta I. Hryhorova ${ }^{* * * * *}$
}

ABSTRACT

The purpose of the article is to develop a comparative description of order fulfillment models by logistics operators, analysis of the estimated average transit time in the Asia - Europe direction. The main approach for studying this problem is a systematic approach that allows to identify technology elements of Ukrainian logistics operators based on electronic commerce and the use of rail transport in the Ukraine - Asia direction, and consider each element as a subsystem and identify bottlenecks. The article presents the technology to organize the work of Ukrainian logistics operators in the needs of the current market, which includes components of automation, artificial intelligence, warehousing and shipping directly to customers by 3PL operators. The materials in the article are of practical value for the professional and productive training of logistics operators, employees of transport companies, for research and teaching staff, in order to improve their professional skills.

KEY WORDS: container transportation, logistics operator, railway transport, system approach.

${ }^{*} \mathrm{PhD}$ in Technical Sciences, Associate Professor at the Department of Transport Systems and Logistics of Ukrainian State University of Railway Transport. E-mail: prymachenko5514-216@uoel.uk, ORCID ID: https//orcid.org/0000-0001-7326-8997

** PhD in Technical Sciences, Associate Professor at the Department of Freight and Commercial Management of Ukrainian State University of Railway Transport, ORCID ID: https//orcid.org/00000001-8546-3183

*** PhD in Technical Sciences, Associate Professor at the Department of Railway Stations and Units of Ukrainian State University of Railway Transport, ORCID ID: https//orcid.org/0000-0002-66406084

**** PhD in Technical Sciences, Associate Professor at the Department of Transport Systems and Logistics of Ukrainian State University of Railway Transport, ORCID ID: https//orcid.org/00000001-6418-998X

***** Postgraduate Student at the Department of Transport Systems and Logistics of Ukrainian State University of Railway Transport, ORCID ID: https//orcid.org/0000-0003-4351-3263 


\section{La tecnología de organización del trabajo de los operadores logísticos ucranianos sobre la base del comercio electrónico}

RESUMEN

El propósito del artículo es desarrollar una descripción comparativa de modelos de cumplimiento de pedidos por operadores logísticos, análisis del tiempo de tránsito promedio estimado en la dirección Asia - Europa. El enfoque principal para el estudio de este problema es un enfoque sistemático que permite identificar elementos de tecnología de los operadores logísticos ucranianos basados en el comercio electrónico y el uso del transporte ferroviario en la dirección Ucrania - Asia, y considerar cada elemento como un subsistema e identificar cuellos de botella. El artículo presenta la tecnología para organizar el trabajo de los operadores logísticos ucranianos en las necesidades del mercado actual, que incluye componentes de automatización, inteligencia artificial, almacenamiento y envío directamente a los clientes por parte de operadores 3PL. Los materiales del artículo son de valor práctico para la formación profesional y productiva de operadores logísticos, empleados de empresas de transporte, para personal investigador y docente, con el fin de mejorar sus competencias profesionales.

PALABRAS CLAVE: transporte de contenedores, operador logístico, transporte ferroviario, enfoque de sistemas.

Introduction

Today's all logistics providers are too aware of the fact that e-commerce business is booming: online sales are estimated to take up $24 \%$ of total sales by 2027 . Companies have been forced to redesign their warehouses and distribution centers in order to meet consumers' demands for fulfilled orders as quickly as possible (Wang, 2010). These days, if a supplier can't keep up with the quick shipping needs of consumers, it's all too easy for those consumers to simply switch to a competitor who can meet their needs (Technologies disrupting logistics..., 2019). Consequently, automation software has become a requirement for any business trying to keep up. Many automation systems typically focus on logistics integration, operational control and/or business control. Automation provides logistics companies with the control of automated machinery, for example, allowing them to sort packages without human employees (Heidegger, 2019). But in order to upgrade to channel production at optimum speed, businesses must optimize their existing operations while implementing new technologies that go far beyond simple automation solutions (Tsareva 
and Omelyanenko, 2020). The most forward-looking companies are improving the logistics order fulfillment by using combinations of innovative robots, artificial intelligence solutions and more to create a highly optimized supply chain that can meet the changing needs of today's consumers (Blanckenberg, 2019; Kulykov, 2020).

Talking about artificial intelligence means using robotics. They are used to track, locate and move inventory within the warehouses. Apart from robots, artificial intelligence is also about big data. When the insights of big data are used along with artificial intelligence, it helps to improve different areas of supply chain like supply chain transparency and route optimization. Robots are quickly becoming one of the most adopted tools in warehouses, thanks to their efficiency and easy implementation for tedious warehouse processes such as unloading, shipment retrieval or pallet stacking (Pndey, 2019).

Beyond robots, logistics providers are also seeing a rise in using unmanned vehicles operated with artificial intelligence and machine vision technologies. A Material Handling Institute survey showed that members expect the adoption of driverless vehicles in warehouses to rise from $34 \%$ to $73 \%$ over the next five years, with more than half of the respondents saying that driverless vehicles have the potential to create competitive advantages. Also, a high level of data protection is important for modern logistics companies. In this business the volume of information transfer is very large, and a better tool than block chain technology for the protection of large amounts of data has not been invented yet (Chornopyska \& Bolibrukh, 2020; Hryhorak et al., 2020). Block chain technology is a special structure for recording a group of transactions (actions), the main advantage of it - the implementation of any operations only when this action is considered confirmed. For example, the transaction will be considered true (confirmed) only after checking its format and signatures (Dobrovnyk et al., 2018). A new era demands new technologies and in today's era of globalization, it's essential for retailers 3PLs and logistics service providers to use these technologies within their operations. In order to stay competitive and thrive in this increasingly mobile, e-commerce driven world.

\section{Methodology}

The simple rule in traditional supply chains was to store maximum possible quantity of every product, everywhere, every time. Supply chains have evolved and are much different 
from what they used to be say 2-3 decades back. Modern supply chains equipped with better information and intelligence are able to predict product demand well in advance, plan accordingly and deliver the items close to when they are needed. The new supply chain rule is to have "the required quantity, of the right product, in the right place, at the right time" (Krasnoff, 2020). The traditional warehouses are not completely fit to cater to this new supply chain rule and this led to the evolution of static warehouses into distribution centers (Dyczkowska \& Reshetnikova, 2020).

The systematic approach was used to identify elements of technology of Ukrainian logistics operators based on e-commerce and the use of rail transport in the direction of Ukraine - Asia. To achieve the aim of the study, two order fulfillment models were investigated (Figure 1).

\section{The $3^{\text {rd }}$ Party Fulfillment Model}



vs. The Self-Fulfillment Model

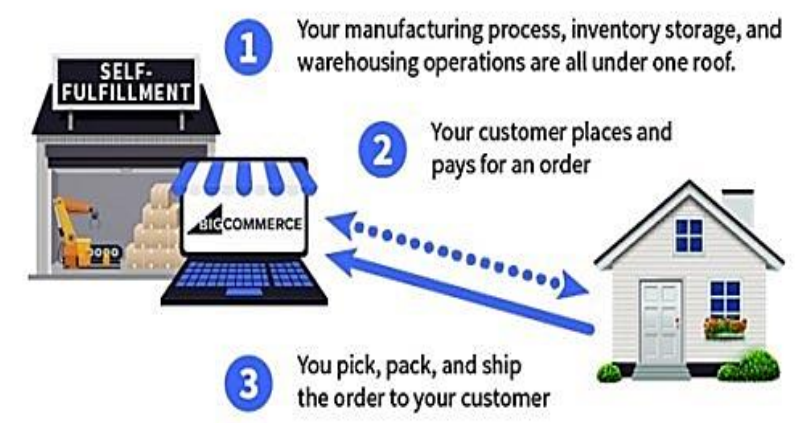

Figure l. The visual of the two order fulfillment models (Gilbert, 2020)

Figure 1 show two most common order fulfillment models - one that uses third-party service providers and the other where you basically handle all the major tasks. There could simply be too many chores that you may not have time to efficiently manage (Sahaidak et al., 2017). The fact is marketing and selling are only half of the equation in business, the other half is getting your products to customers fast. Fulfillment centers enable ecommerce merchants to outsource warehousing and shipping (Gilbert, 2020). This relieves business of the necessary physical space to store all products, which is beneficial for merchants without the capacity to directly manage inventory. Sellers send merchandise to the fulfillment center, and the outsourced provider ships it to customers for them. Fulfillment centers make 
inventory management much easier and allow store owners more time to focus on other areas of their business (Zorini, 2020).

To represent how fulfillment works the authors compared the best logistic companies in China (Table 1) and Ukraine (Table 2).

Table 1. Comparison dashboard of the top Mainland China and Hong Kong-based fulfillment centers

\begin{tabular}{|c|c|c|c|}
\hline $\begin{array}{l}\text { Fulfillment } \\
\text { center }\end{array}$ & Geography & Offered services & Cooperation \\
\hline ZhenHub & $\begin{array}{l}\text { Has fulfillment centers in } \\
\text { ll different countries and } \\
\text { regions, including } \\
\text { Mainland China, Hong } \\
\text { Kong, USA, UK, Germany, } \\
\text { Italy, France, Australia, } \\
\text { Taiwan, the Philippines } \\
\text { and Korea. }\end{array}$ & $\begin{array}{l}\text { - Storage. } \\
\text { - Pick and pack. } \\
\text { - Shipping. } \\
\text { - Co-packing. } \\
\text { - Returns. }\end{array}$ & $\begin{array}{l}\text { Work with shipping } \\
\text { companies that include } \\
\text { DHL, China Post, FedEx } \\
\text { and SF Express. Also } \\
\text { offer full e-commerce } \\
\text { integrations for all major } \\
\text { e-commerce platforms } \\
\text { like Shopify, Woo } \\
\text { commerce and Amazon. }\end{array}$ \\
\hline DHL Hong Kong & $\begin{array}{l}\text { Fulfillment center in Hong } \\
\text { Kong, warehouse in Hong } \\
\text { Kong, also several other } \\
\text { offices and warehouses in } \\
\text { Mainland China. }\end{array}$ & $\begin{array}{l}\text { - Inbound freight. } \\
\text { - Service Level } \\
\text { Agreements. } \\
\text { - Receiving, } \\
\text { handling and } \\
\text { shelving. } \\
\text { - Inventory } \\
\text { tracking. } \\
\text { - Pick and Pack } \\
\text { service. } \\
\text { - Returns } \\
\text { handling. } \\
\text { - Last-mile } \\
\text { delivery services. } \\
\text { - Inventory. }\end{array}$ & \\
\hline Shipwire & $\begin{array}{l}\text { Global fulfillment } \\
\text { company and a brand of } \\
\text { Ingram Micro, that owns } \\
\text { more than } 154 \text { fulfillment } \\
\text { centers in } 45 \text { countries } \\
\text { around the globe. }\end{array}$ & $\begin{array}{l}\text { - Same-day order } \\
\text { processing. } \\
\text { - Storage. } \\
\text { - Return shipping } \\
\text { optimization. } \\
\text { - Order } \\
\text { optimization } \\
\text { (offers the most } \\
\text { competitive rates } \\
\text { based on multiple } \\
\text { factors). }\end{array}$ & $\begin{array}{l}\text { They work with multiple } \\
\text { well-known shipping } \\
\text { companies that include } \\
\text { DHL, Hong Kong Post, } \\
\text { FedEx and SF Express. }\end{array}$ \\
\hline
\end{tabular}




\begin{tabular}{|c|c|c|c|}
\hline & & $\begin{array}{l}\text { - Custom } \\
\text { packaging. } \\
\text { - Kitting \& virtual } \\
\text { kitting. }\end{array}$ & \\
\hline EXchain & $\begin{array}{l}\text { Fulfillment center based in } \\
\text { Hong Kong, warehousing } \\
\text { network in Hong Kong, } \\
\text { Europe (Germany), the } \\
\text { United States and China. }\end{array}$ & $\begin{array}{l}\text { - Storage. } \\
\text { - Shipping. } \\
\text { - Pick \& Pack. } \\
\text { - Package } \\
\text { scanning. } \\
\text { - API service } \\
\text { available - orders } \\
\text { can be handled } \\
\text { automatically. } \\
\text { - Same day } \\
\text { delivery. }\end{array}$ & $\begin{array}{l}\text { Their online system } \\
\text { automatically imports } \\
\text { orders using an API } \\
\text { service from all major e- } \\
\text { commerce platforms like } \\
\text { Wish, Alibaba, Amazon } \\
\text { and eBay. }\end{array}$ \\
\hline Send from China & $\begin{array}{l}\text { Fulfillment centers and } \\
\text { warehouses located in } \\
\text { Shenzhen, Shanghai and } \\
\text { Dongguan. }\end{array}$ & $\begin{array}{l}\text { - Stocking. } \\
\text { - Storage. } \\
\text { - QC and product } \\
\text { labeling. } \\
\text { - Package } \\
\text { scanning. } \\
\text { - Shipping. }\end{array}$ & $\begin{array}{l}\text { They also offer easy } \\
\text { online store integration } \\
\text { with Web Service APIs } \\
\text { that allows sellers to } \\
\text { track orders, manage } \\
\text { inventory, and keep an } \\
\text { eye on product } \\
\text { information and order } \\
\text { processing. }\end{array}$ \\
\hline Easyship & $\begin{array}{l}\text { Has offices and } \\
\text { warehouses in Singapore, } \\
\text { Netherlands, Australia and } \\
\text { the United States. }\end{array}$ & $\begin{array}{l}\text { - Storage. } \\
\text { - Pick \& Pack. } \\
\text { - Shipping. }\end{array}$ & $\begin{array}{l}\text { Full e-commerce } \\
\text { integration for all major } \\
\text { e-commerce platforms } \\
\text { like Alibaba, Amazon and } \\
\text { Shopify also connects } \\
\text { sellers with shipping } \\
\text { companies like DHL, } \\
\text { FedEx and others. }\end{array}$ \\
\hline
\end{tabular}

Source: F. Gronkvist (2019).

\section{Results and Discussion}

On June 8, 2020, the first direct container train arrived from China to the Liski department of Ukrzaliznytsia in Kyiv. The peculiarity of this train is that goods were delivered from the northern regions of China, which is difficult to organize by the sea due to the distance from China's seaports (Boldyreiva \& Gryshko, 2020). It is planned to organize the running of these trains on an ongoing basis. The train covered the distance of $9000 \mathrm{~km}$ in 15 days. The train included 31 platforms with 41 forty-foot containers. They brought to Ukraine drilling equipment, bicycle parts, furniture, household goods, personal protective 
equipment, etc. The Ukrzaliznytsia informed that the train also transported gas trimmers and medical equipment. Also, in plans to ensure the entry of container trains to the branches of UZ Liski in Kharkiv and Dnipro (Kostiuchenko, 2020). A container train provides faster speed than shipping by sea. This is both cost savings and the ability to build new production chains based on the quick delivery of components to enterprises. Carriage in such a train is approximately two times more expensive than by sea. But by sea it takes 45 days. And the train is interesting for those who are interested in speed of delivery (Figure 2).

The market of container transportation in Ukraine shows a positive dynamic of growth by an average of $13-15 \%$ annually (Figure 3). According to this, the growth of container traffic is on the railway. Thus, for the first 4 months of 2020, 90 thousand TEU (TEU or twenty-foot equivalent) was transported by rail as part of container trains, which is more than in 2 times more than the volume of traffic for the same period in 2019 (Kulak, 2020).

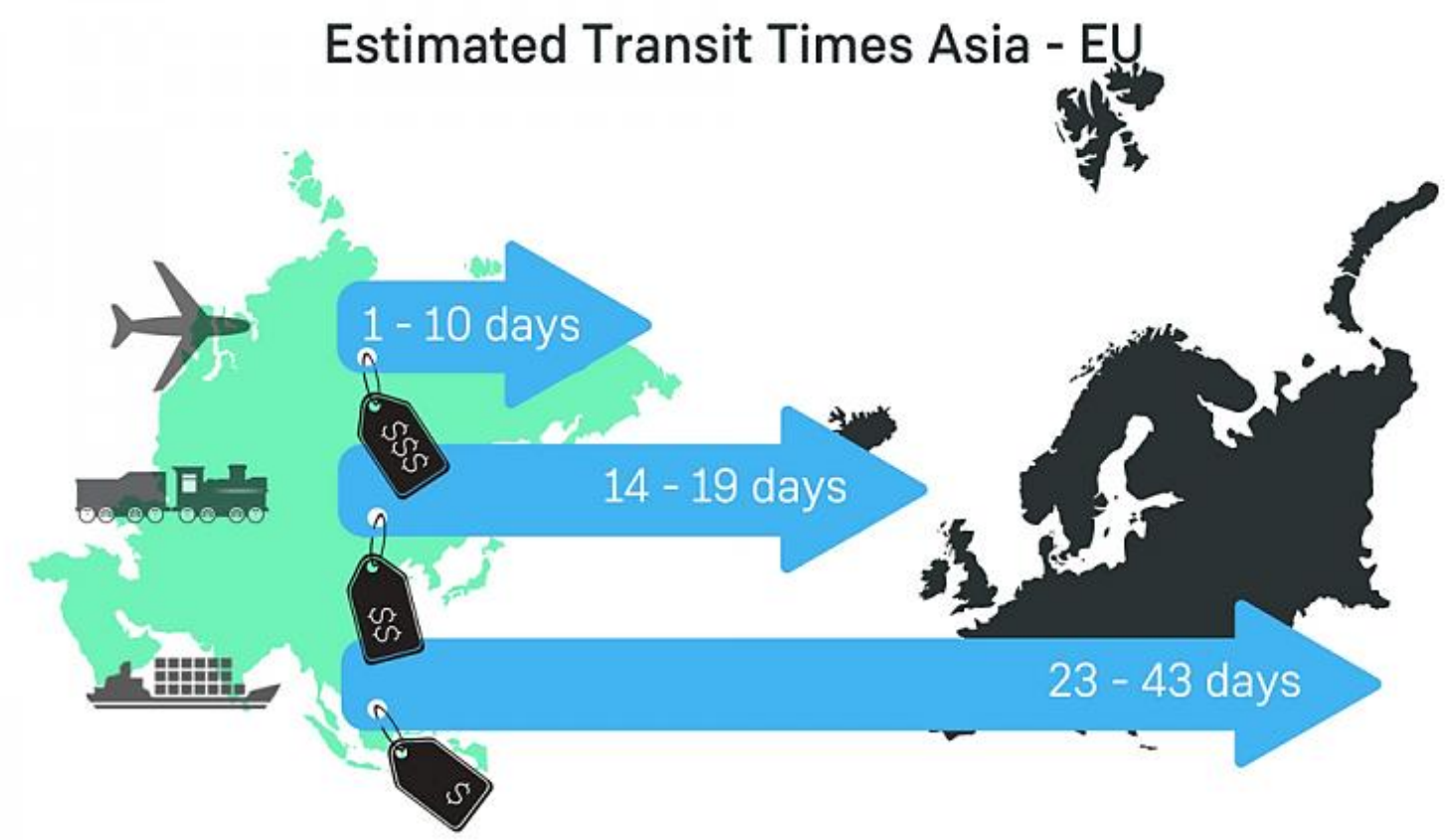

Figure 2. Average estimated transit times Asia - Europe (Rail freight from China..., 2019). 


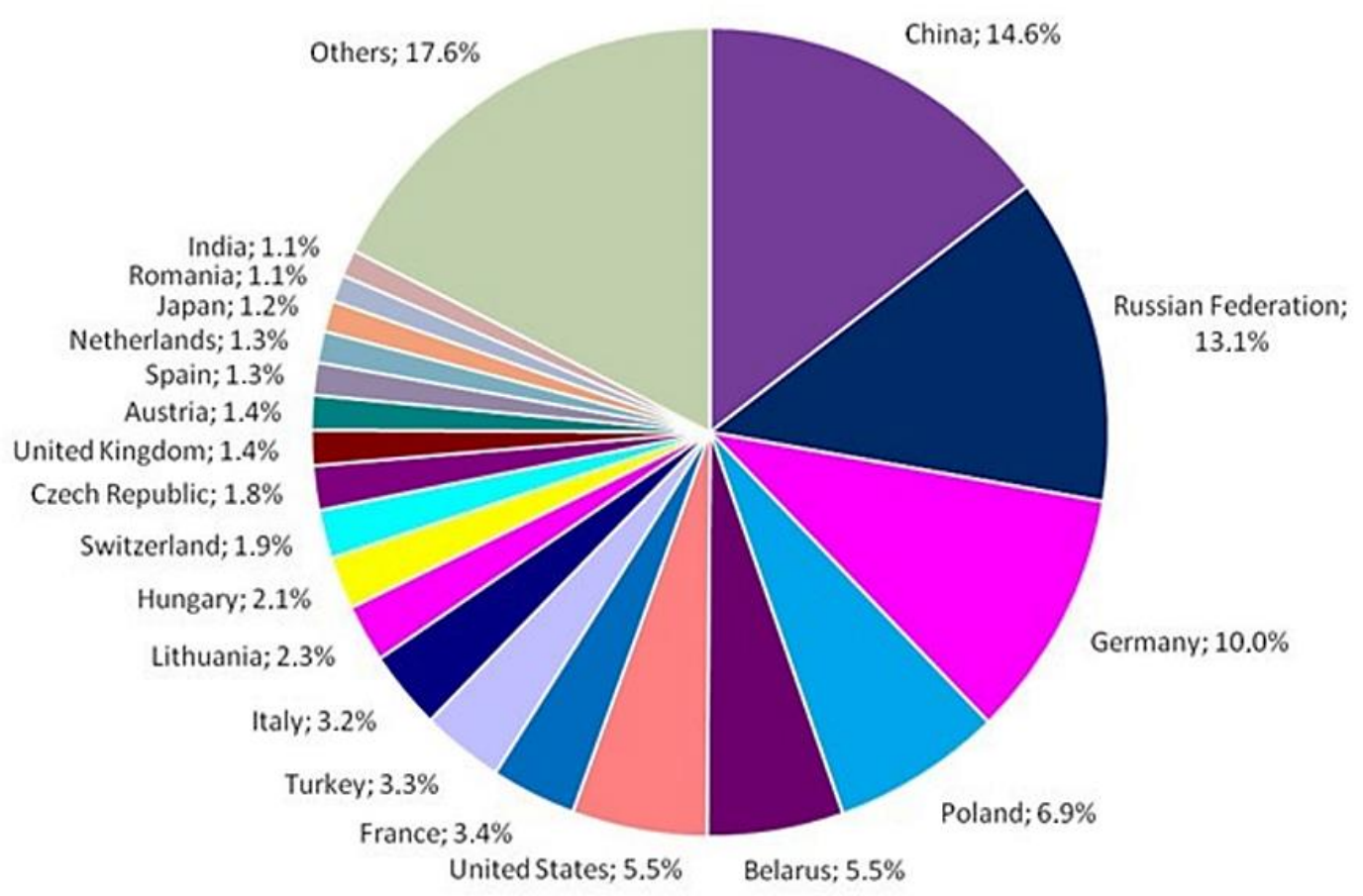

Figure 3. Main trade partners of Ukraine in \% from total volume (Import from other countries to Ukraine) in January-March 2019 (Ukraine's foreign trade..., 2019)

Container rail transportation is a really reliable, cheap and convenient way of transportation, which will be able to compete to the sea and air mode of transport in the combination of China-Ukraine, because if you compare rail transportation with air, it is cheaper, and if you compare with the sea mode of transport then by rail faster. Ukrzaliznytsia and Ukrposhta intend to discuss cooperation in the delivery of goods and correspondence from China by rail after the first direct container train arrived from China. The management of Ukrposhta announced their interest in the container transportation service by this train. There are some reasons why do they need to cooperate. The number of orders of Ukrainians on AliExpress for 10 months of 2019 increased by 70\% - this brought Ukraine to the 2-nd place in terms of growth rates on the mappelplex. This was reported by the press service of Ukropshta. In the total cost of goods sold on AliExpress in 2019, Ukraine entered the top 10 countries in the world. Ukrposhta for the three quarters of 2019 has already delivered more than 20 million items from China, and most of them are goods from online stores (Figure 4). They are ordered by Ukrainians aged 24-35 years, more than half of them shop on AliExpress via a smartphone (Ukrainians ranked second..., 2019). 
The highest demand for products with AliExpress is among residents of the Kyiv, Dnipro and Kharkov regions. The company delivered $56 \%$ of the parcels ordered by the Ukrainians from China to these regions. Also, Ukrposhta interested in having a representative of Aliexpress office in Ukraine (Ukrainians ranked second..., 2019). The Nova Poshta Global company has opened another way of delivering parcels from the Chinese trading platform AliExpress to Ukraine by train also. According to the company, it is in 2 times faster than similar shipments on the market. Nova Poshta delivered the first test batch of parcels by train, convinced of the reliability of this method, and now plans to use it on a regular basis. "The key advantage of the railway is a clear route: trains move on schedule, which allows customers to meet delivery deadlines. In addition, railway containers allow to combine e-commerce shipments with the cargo of business customers, which allows to meet the needs of various segments" - said Olga Volodina, Deputy Director of Nova Poshta Global (Karpus, 2020).

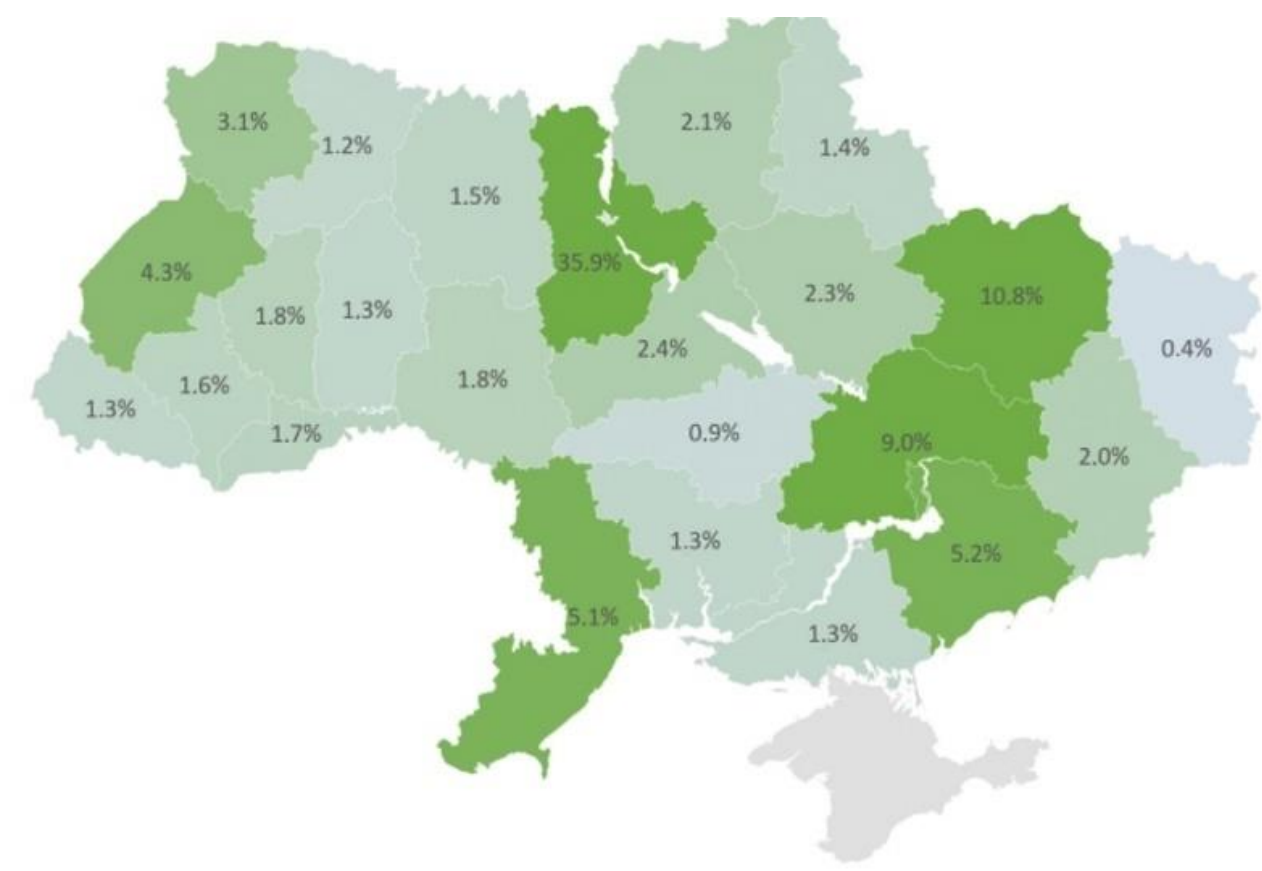

Figure 4. Distribution of departures of Ukrposhta from China in September 2019 (Ukrainians ranked second..., 2019).

Ukraine took the second-place ordering from Aliexpress after Russia. Russia has advantage because there located warehouse of Aliexpress. There is the main and only, as of 
2019, its own AliExpress sorting and processing center. Chinese sellers rent 21000 square meters of heated and ventilated storage facilities. In order to accelerate delivery in the Russian Federation, Chinese sellers have already delivered to the warehouse the most popular goods in some quantities. For this, sellers paid - those stores where you buy them on Aliexpress (Kononenko, 2020). Business in Ukraine can also ensure the simultaneous delivery, storage and dispatch of their goods. Most Ukrainian sellers bring their goods to Ukraine from China. That is why 3PL operators can help businesses. In Ukraine, the fulfillment market is under development. It's very young industry. The direction of fulfillment is handled by Nova Poshta Logistic, the only company on the Ukrainian market working according to the formula "fulfillment + delivery". The customers of this service today are Rosetka, Allo, WOG, Nestle, Philip Morris, Garna mama and other companies. The fulfillment services in Ukraine are also provided by Denka Logistics, Zammler, Raben, UVK and other companies. All represented companies can integrate cargo delivery, storage and dispatch directly to customers (Yarovaya, 2017). Let's compare the capabilities of the top companies based in Ukraine.

Some customers import cargo to Ukraine using other self-dependent delivery companies from abroad, for example, Nova Poshta picks up for storage directly from customs. The Table 2 shows that fulfillment powers are located in the capital and the region mostly. In the coming years, NP Logistics plans to develop a branch network in cities with a population of millions, a branch has already been opened in Kharkiv (Yarovaya, 2017). Why it has to be used and important for business: building logistics on your own is very expensive, often Ukrainian online stores outsource a part of the logistics process, but today in Ukraine you can outsource the entire logistics process from storage to packaging to the final customer. It's difficult and expensive to build logistics on your own. Firstly, investments in the warehouse: arrangement of workplaces, warehouse equipment, loading equipment, rent. Renting a good warehouse costs hundreds of thousands of hryvnias per year. Secondly, implementation of Information Technologies. It is impossible to conduct logistics on a large scale without a good automation of the warehouse system. Installing of good software can costs hundreds of thousands of dollars. The total costs of premises, technology, equipment and people are measured in millions. This business is very high tech. The fulfillment market 
in Ukraine is still so young that it is worth investing in infrastructure development, debugging technical processes, structuring the market, and then robotizing.

Table 2. List of top Ukrainian companies which provide 3PL logistics

\begin{tabular}{|c|c|c|}
\hline Company & $\begin{array}{l}\text { Stocking space, } \\
\text { square meters }\end{array}$ & Services \\
\hline $\begin{array}{ll}\text { Nova } & \text { Poshta } \\
\text { Logistic } & \end{array}$ & $\begin{array}{l}30000 \text { in Kyiv } \\
\text { region }\end{array}$ & $\begin{array}{l}\text { - Acceptance of goods at the warehouse (rejection, } \\
\text { stickering). } \\
\text { - Storage of goods. } \\
\text { - Picking orders. } \\
\text { - Registration of accompanying documentation } \\
\text { (check, warranty card, EH). } \\
\text { - Order packaging. } \\
\text { - Returns Processing. }\end{array}$ \\
\hline Denka Logistics & $\begin{array}{l}20000 \text { in } \\
\text { region }\end{array}$ & $\begin{array}{l}\text { - Storage and shipment. } \\
\text { - Accepting orders online. } \\
\text { - Cross-docking, selection of goods from stock. } \\
\text { - Accounting for serial numbers. } \\
\text { - Packing and delivery. } \\
\text { - Sticking of goods. } \\
\text { - Taking goods from the supplier. }\end{array}$ \\
\hline Zammler &  & $\begin{array}{l}\text { - Acceptance of goods from the supplier. } \\
\text { - Storage. } \\
\text { - Order processing (call center). } \\
\text { - Complete set, packing of the order. } \\
\text { - Automatic calculation of the cost of delivery of the } \\
\text { order. } \\
\text { - Delivery to the door. } \\
\text { - Return processing. } \\
\text { - Payment service (receiving payment from the } \\
\text { recipient). } \\
\text { - Photo studio services. }\end{array}$ \\
\hline
\end{tabular}

According to the new possibility of delivering containers by rail from China, it is important to consider the possibility of cooperation between Ukrainian logistics companies, companies providing 3PL logistics and Ukrzaliznytsia. This can solve delivery and stocking problems for Ukrainian business and Chinese business in Ukraine. Major solutions include:

- $\quad$ optimal delivery time and cost;

- clear route - trains run on schedule without deviations and delays that can guarantee customers timeliness of delivery; 
- $\quad$ railway containers allow to combine administration of e-commerce with loads of business customers that can satisfy the needs of various segments;

- $\quad$ it will provide an opportunity to consider the storage of various popular goods from china for buyers of AliExpress, Alibaba and other giants of Chinese production and distribution, which will accelerate and increase the demand for using this type of service, as well as attract economic investment in the development of this infrastructure;

- $\quad$ it will increase the frequency of trains from China to Ukraine - every week and with a subsequent increase in frequency.

\section{Conclusions}

The conclusion is that all parties have the benefit of participation in the delivery of goods in such a way. For logistic companies: expanding the services for online businesses, increasing the speed of delivery processing, the ability to lease warehouses for goods of popular foreign online stores. For local business and e-commerce: automation of logistics and inventory processes, reducing storage costs. It reduces the percentage of errors in the selection of orders, allows you to track warehouse performance indicators and offer the best method of delivery and payment for customers. And most importantly, by transferring logistics processes to the hands of professional providers, online business can focus on its main functions - promoting and increasing turnover. For Ukrainian railway company: new contracts with leading suppliers of logistics and container rental, demand for increasing the frequency of import of goods by rail and expanding the geography of delivery.

Yesterday, choosing a fulfillment operator, price and quality were decisive, but today only the additional range of services that operators can provide becoming increasingly important. Another current trend for e-commerce may be the use of sharing logistic as one of the sharing economies segments that covers the issues of sharing storage, transport and personnel services (loading, unloading, accounting, and many other operations). Logistics and fulfillment are promising areas because the online market is started to grow.

\section{References}

Blanckenberg, N. (2019). Extensive list of fulfillment companies and services for ecommerce. Retrieved from https://blog.storeya.com/2018/11/list-of-fulfillment-companies/ 
Boldyreiva, L., \& Gryshko, V. 2020. European experience of smart-technology implementation in logistic process management. Economics and State, 4, 39-43. doi:10.32702/2306-6806.2020.4.39

Chornopyska, N., \& Bolibrukh, L. (2020). The influence of the COVID-19 crisis on the formation of logistics quality. Intellectualization of Logistics and Supply Chain Management, 2, 88-98. doi:10.46783/smart-scm/2020-2-7

Dobrovnyk, M., Herold, D., Fiurst, E., \& Kummer, S. (2018). Blockchain for ta in logistics: what to do and where to start? Logistics, 4, 21-29.

Dyczkowska, J., \& Reshetnikova, O. (2020). New technological solutions in logistics on the example of logistics operators in Poland and Ukraine. SMART Supply Network, 1, 47-69. doi:10.1007/978-3-319-91668-2_3.

Gilbert, N. (2020). 20 best order fulfillment services \& companies of 2020. Retrieved from https:/financesonline.com/top-20-order-fulfillment-services/

Gronkvist, F. (2019). Top 8 fulfillment centers in China and Hong Kong. Retrieved from https:/www.chinaimportal.com/blog/fulfillment-centers-china-hong-kong/

Heidegger, J. (2019). Warehouse \& distribution center best practices for your supply Chain. Retrieved from https:/legacyscs.com/warehouse-and-distribution-center-ll-best-practices/

Hryhorak, M., Trushkina, N., Popkowski, T., \& Molchanova, K. (2020) Digital transformations of logistics customer service business models. Intellectualization of logistics and Supply Chain Management, 1, 57-75. doi:10.46783/smart-scm/2020-1-6.

Karpus, V. (2020). Nova Poshta launched the delivery of parcels from China by train. Retrieved from https://novaposhta.ua/ru/fulfilment

Kononenko, M. (2020). Aliexpress warehouse in Russia, in Moscow: Where it is located and how it looks. Retrieved from https://pokupar.com/sklad-alijekspressr\#.XwZLAi_5ZQI

Kostiuchenko, A. (2020). Information and consulting center. 10 questions about the direct container train Ukraine-China. Retrieved from https://cfts.org.ua/spetsproekty/10_voprosov_o_pryamom_konteynernom_poezde_ukraina_ kitay

Krasnoff, B. (2020). The best e-commerce fulfillment services. Retrieved from https://www.pcmag.com/picks/the-best-e-commerce-fulfillment-services

Kulak, O. (2020). In 2019, Ukrzaliznytsia's container traffic increased by 14.64\%. Retrieved from https://railinsider.com.ua/v-2019-perevezennya-kontejneriv-ukrzaliznyczeyu-zroslona-1464/

Kulykov, A. (2020). Logistics and fulfillment trends in e-commerce. Retrieved from https://www.shopolog.ru/metodichka/logistics/trendy-logistiki-i-fulfilmenta-v-ecommerce/ 
Pndey, K. (2019). How ai is revolutionizing global logistics and supply chain management. Retrieved from https:/readwrite.com/2019/04/15/how-ai-is-revolutionizing-globallogistics-and-supply-chain-management/

Rail freight from China to Europe - rates \& transit time. (2019). Retrieved from https:/www.sino-shipping.com/rail-freight-china/

Sahaidak, M., Zavyalova, M., \& Kotane, I. (2017). Marketing strategy of enterprise positioning in the market of logistic services. Periodyk Naukowy Akademii Polonijnej, 5, 107-120. doi:10.23856/2412

Technologies disrupting logistics order fulfillment. (2019). Retrieved from https:/transmetrics.eu/blog/logistics-order-fulfillment-technologies/

Tsareva, N. A.; Omelyanenko, S. Y. (2020). Remote work: development of employee digital competence, Revista de la Universidad del Zulia, 11 (31), 131-140. DOI: http://dx.doi.org/10.46925//rdluz.31.10

Ukraine's foreign trade in goods - import. (2019). Retrieved from https://open4business.com.ua/ukraines-foreign-trade-in-goods-import-jan-march-2019/

Ukrainians ranked second in the world in terms of growth in the number of orders on AliExpress. (2019). Retrieved from https://www.epravda.com.ua/rus/news/2019/11/11/653573/

Wang, Y. (2010). Framework of evaluating e-commerce based on business process. IC4E 2010 - 2010 International Conference on e-Education, e-Business, e-Management and e-Learning, 499-501. doi:10.1109/IC4E.2010.79

Yarovaya, M. (2017). How the fulfillment of the Nova Poshta company works. Retrieved from https:/ain.ua/2017/02/09/kak-rabotaet-fulfilment-novoj-poshty-fotoreportazh-iz-centra-vbrovarax/

Zorini, C. (2020). Ecommerce fulfillment services: The best order fulfillment companies. Retrieved from https://www.loadingcenter.co.uk/e-commerce-fulfilment/ 